\title{
A Standard Guideline for Children With Autism Spectrum Disorder to Involve in Therapeutic Horseback Riding
}

\author{
Kamaruzaman Soeed ${ }^{1 *}$, Fatin Aqilanajwa Adenan ${ }^{2}$, Nur Fadilah Darmansah ${ }^{3}$, Izwyn \\ Zulkapri $^{4}$ \\ ${ }^{1,2,3,4}$ School of Biomedical and Health Science, Universiti Teknologi Malaysia, 81310 Skudai, Johor, Malaysia. \\ *Corresponding: ${ }^{1}$ skamaruzaman@biomedical.utm.my,
}

\begin{abstract}
Positive evidences on therapeutic horseback riding (THR) for autism spectrum disorder (ASD) is undeniable. By using the natural movement of a horse, it become one of the approaches for a treatment tool in individuals with ASD. However, the risk of injury associated with THR should be considered. A child with ASD have possibilities to scream and excited on horse. The horse instincts will assume that unexpected noises as a threat so they have tendency to flight during the THR session. Hence, the objective of the study is to propose a standard guideline for ASD children to involve in THR as a prerequisite before participating in the therapy session. The guideline is design based on the learning pyramid which focuses on sensory domain that is at the bottom level of the pyramid. There are seven (7) elements in the sensory domain, but only four (4) elements are involved in the standard guideline. The elements are Tactile, Vestibular, Proprioception and Auditory. This standard guideline derived by sensory elements that relate to therapeutic horseback riding related activities. This study acknowledge that the proposed guideline is comprehensive, thus the proposed guideline can be integrated with recognition that those guidelines can be developed with further refinement. Moreover, these guidelines face challenges in recognizing the nature of common guidelines associated with different beliefs, philosophies, and school of thought. Nevertheless, these guidelines represent an essential first step as a primary resource to support and direct health care professionals, teachers, instructors, and consumers as well as therapeutic horseback riding community.
\end{abstract}

Keywords: Therapeutic horseback riding (THR), Autism spectrum disorder (ASD), Standard guideline.

\section{INTRODUCTION}

For many years, horse riding therapy for disable kids has been practiced in Malaysia as alternative therapy. It was first begun in 1994, Riding for the Disabled Association (RDA) Malaysia is run as a voluntary, non-profit making organization which provides opportunities for children and young adults with various disabilities for horse riding therapy. Therapeutic horseback riding (THR) activity has been growth in line with the increasing number of RDA and private centres in Malaysia. To date, there are 11 RDA centres has established in this country. Autism Spectrum Disorder (ASD) is a neurodevelopmental disorder that affects multiple subsystems including social communication, behavioural, cognitive and perceptuomotor domains [1]. Core impairment in ASD are on three major deficits include social communication difficulties as well as the presence of stereotype and repetitive behaviours and interests [2]. ASD also have cognitive difficulties and sensorimotor impairments $[3,4]$.
ASD can be categorized into High Functioning Autism Spectrum Disorder (HFA) and Low Functioning Autism (LFA) [5]. There are distinct characteristics between both categories. Children with LFA typically present with restricted language, behavioural and emotional issues, severe memory impairment [6]. LFA children also present with sensory-related issues [7]. While children with HFA typically present as having developed language and cognitive abilities, but experience social difficulties, and sensory and motor issues [8].

Recently, many researches have been conducted on autism spectrum disorder (ASD). Therefore, this study correlates the information on ASD characteristics in each severity level of ASD with THR activity. In which clarify the need of THR standard guideline. According to DSM-5 Autism Spectrum Disorder [9], there are three severity level of ASD. There are level 1, level 2 and level 3. Level 1 is known as 'requiring support' and associate with high functioning autism. They might have difficulty initiating social interactions and may appear to have decreased interest in social interactions. Then, level 2 is known as 
'requiring substantial support' which marked by deficits in verbal and nonverbal social communication skills, limited initiation of social interactions and reduced or abnormal response to social overtures from others. Next, level 3 is known as 'requiring very substantial support' and associate with severe autism. They are severe deficits in verbal and nonverbal social communication skills cause severe impairments in functioning; very limited initiation of social interactions and minimal response to social overtures from others. Those 3 levels distinguish the severity of the autism. Thus, this study is very selective and particular about the selection of the subjects. The THR standard guideline is propose in order to identify each child with ASD able to proceed with THR session or not. In 2013, the American Psychiatric Association added sensory sensitivities to the symptoms that help diagnose autism [2]. Sensory issues often accompany autism. Autism's sensory issues can involve both hypersensitivities (over-responsiveness) and hypo-sensitivities (under-responsiveness) to a wide range of stimuli.

The concern of this study is to propose the standard guideline for therapeutic horseback riding (THR) as a prevention of high-risk injury and safety of ASD children. There is evidence mention that very little data on how horses behave, specifically in equine assisted activity or therapy (EAA/T) sessions, and what motivates that behaviour [10]. Besides, the risks of injury associated with horseback riding therapy should also be considered before recommending this therapy [11].

Previous research has revealed that high risk injuries are more to autism children [12]. Children with autism were at least two to three times more likely than typical children to experience an injury that needed medical attention. The characteristic in ASD children itself being the reason why ASD children was a high-risk group [13]. Their symptoms of emotional abnormalities were often irritated in children with ASD and often lead to express behaviours such as tantrums and aggression. Majority of the research conduct regarding the risk of injuries in horseback therapy was related to equine therapies such as EAA/T and hippotherapy (HIP). As explained, it is clear that THR become recognized among the community. They start to involve and commits with THR session. Thus, THR become one of the alternative therapies for ASD kids. However, one major drawback of this approach is regarding the safety. The risk of injury associated with horseback riding therapy should be viewed. A reasonable approach to tackle this issue could be to come out with a standard guideline.

As to prioritize the safety aspects, a standard guideline is needed for ASD children to involve in THR as a prerequisite before participating in the THR session. Children with ASD have possibilities to scream and excited on horse. The horse instincts might assume that unexpected noises or a sudden movement as a threat [14]. So, the horse has tendency to flight during THR session. There would therefore seem to be a definite need for this study to propose a standard guideline for ASD children to get involve in THR.

\section{METHODOLOGY}

The safety aspect is a prime concern for this study which explains the need of THR standard guideline. As each severity levels autism characteristics has been clearly described above. It is shown that, there is a requirement to assess the level of the ASD kids before participating in THR session. ASD kids have their own nature of behaviour, while horses also have their own nature behaviour as a prey animal. Fight ad flight is a nature for a horse which could be a possible risk for human who deal with them.

In order to propose the standard guideline for THR, the following Figure 1 shows Pyramid of Learning has become a reference [15]. The lower level of the pyramid consists of sensory elements. Based on the pyramid, there are seven (7) sensory elements, but this study only focuses to four (4) sensory elements; Tactile, Vestibular, Proprioception and Auditory. The content in the standard guideline related to each sensory element is specific to THR activities.

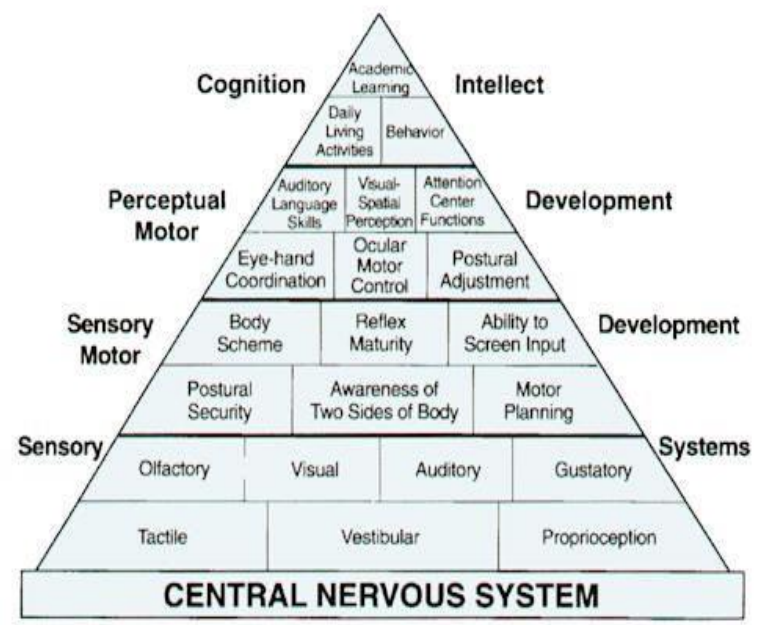

Figure 1: Pyramid of Learning.

It is important to understand the sensory levels of children with ASD as it involves with the safety issues. There are seven (7) sensory elements involve in the pyramid of learning. Place in the bottom of the pyramid, sensory elements are the basic systems need to be focus on the development of a child. Olfactory and Gustatory elements do not involve in the standard guideline as it is not directly involved with the physical activities. This standard guideline is in need to be implemented as it is to refine the safety issues regarding THR sessions.

Nature of the horse is fight and flight which they are very sensitive to a sudden movement, loud voices or screaming. While the nature of ASD kids makes them have possibilities to scream on horses, and have potentials to jump from the horse. Thus, this study come out with a standard guideline that meet the sensory levels of ASD children. THR elements is built based on the learning pyramid. Then, each item in the THR standard guideline is built referring to the DSM-5 Autism Spectrum Disorder 
guideline and criteria exemplars and sensory processing information [9]. The criteria are in line with the THR activities.

The scoring guideline also has been inspired and referred to some of screening rating scale to detect autism in early development and this screening rating scale has been used by parents, caregiver and teacher at the school. The Social Communication Questionnaire (SCQ) is a parent-report measure intended to screen for characteristics of Autism Spectrum Disorder (ASD) [16]. This SCQ has two forms available, one that is proposed to examine an individual's developmental history, and another is to gathers information regarding the individual's current, everyday functioning (the past three months). This questionnaire takes about 10 minutes for a parent or caregiver to complete the SCQ, and about 5 minutes for scoring and only can be used individuals for 4 years old and above. However, this SCQ good screening measure in the general population for children who have not done any clinical evaluation.

Therefore, based on reference from SCQ, this study emphases on four sensory elements in the scoring guideline to evaluate and analyse the level sensory problem in ASD children. A scoring form is design as a guideline to evaluate ASD children based on their reaction and behaviour by focusing on sensory of tactile, vestibular, proprioception and auditory. The scores are according to the scale by level of problem from 'serious problem' to 'not at all a problem' by using a scoring guideline. This scoring guideline is for therapist, instructor, parents or guardian, health care professionals, teachers, and therapeutic horseback riding community to observe level of sensory of ASD children. The propose standard guideline as an approach to reduce any occurrence and accidents or serious injuries during THR session.

In THR standard guideline, there are few scores need to evaluate by parents, guardians or therapist to determine either the ASD kids able to proceed with THR or not. If the children with ASD is not passing a standard score, further consultation with their therapist is needed. All ASD children can participate in THR session, but there is possible risk. It is important to identify the sensory level of the kids before participate in THR session as it led to safety matter. The kids which have problem with the sensory still can proceed with THR but, the risk is higher compared to the one who not having the sensory problem. Up to now, the standard guideline has been outlined. Many previous studies have performed an intervention by health professional to encounter the sensory issues of a child with ASD. However, this study only intending to recognize the sensory issue in ASD children as prerequisite before participate in THR session as to prioritize the safety of both ASD kids and horses. Hence, the THR standard guideline is propose as the objective in this study.

\section{RESULTS}

In THR Standard Guideline, there will be four (4) sensory elements from the learning pyramid involve in constructing the guideline. The assessor should evaluate each item with the scale given. The scores of this guideline will determine either the ASD child able to proceed with THR or not. If the scores are not meet to the passing items, the ASD child will not be recommend to proceed for THR session and need further consultation with their therapist. The following are Table 1 and Table 2 that describe the scale and score.

Table 1 Score; Level of Problem.

\begin{tabular}{|l|l|l|l|}
\hline \multirow{2}{*}{} & $\mathbf{1}$ & $\begin{array}{l}\text { Serious } \\
\text { problem }\end{array}$ & $\begin{array}{l}\text { The child always shows } \\
\text { the criteria or refuses to } \\
\text { perform task }\end{array}$ \\
\cline { 2 - 4 } & $\mathbf{2}$ & $\begin{array}{l}\text { Moderate } \\
\text { problem }\end{array}$ & $\begin{array}{l}\text { The child often shows the } \\
\text { criteria or refuse at the } \\
\text { beginning, but perform the } \\
\text { task well after that }\end{array}$ \\
\cline { 2 - 4 } & $\mathbf{3}$ & $\begin{array}{l}\text { Minor } \\
\text { problem }\end{array}$ & $\begin{array}{l}\text { The child rarely shows the } \\
\text { criteria or able to perform } \\
\text { task with helps and } \\
\text { guidance }\end{array}$ \\
\cline { 2 - 4 } & $\mathbf{4}$ & $\begin{array}{l}\text { Not at all a } \\
\text { problem }\end{array}$ & $\begin{array}{l}\text { The child never shows } \\
\text { the criteria or able to } \\
\text { perform task } \\
\text { independently }\end{array}$ \\
\hline
\end{tabular}

Table 2 Score to proceed with THR or oppositely.

\begin{tabular}{|c|c|c|}
\hline Score & Reason & Remark \\
\hline $\mathbf{1}$ & $\begin{array}{c}\text { Require further consultation } \\
\text { with therapist }\end{array}$ & X \\
\hline $\mathbf{2 / 3 / 4}$ & Proceed with THR & \\
\hline
\end{tabular}

\subsection{Tactile (Touch)}

The tactile system is important to allow a child to gain knowledge of things around them and to develop a sense of self in relation to others. Child with low sensory sensitivity will lead to lack of good coordination. Tactile sensitivities can affect the ability of a child. A child with a lack of good touch may develop tactile defensiveness or tactile seeking behaviour [17]. The tactile system, or sense of touch, refers to the information we receive though the receptors in our skin. Touch is considered one of our most basic senses [18]. The following is Table 3 which justify the tactile sensory processing that need to be assess on children with ASD before participate in THR session. 
Table 3 Tactile

\begin{tabular}{|c|c|c|c|c|c|c|c|}
\hline \multicolumn{8}{|c|}{ Tactile } \\
\hline \multirow{2}{*}{ Items } & \multirow{2}{*}{ Justification } & \multicolumn{4}{|c|}{ Scores } & \multicolumn{2}{|c|}{ Marks } \\
\hline & & 1 & 2 & 3 & 4 & $\checkmark$ & $x$ \\
\hline $\begin{array}{l}\text { The child } \\
\text { reluctant to } \\
\text { touch fur and } \\
\text { touch the } \\
\text { horse. }\end{array}$ & $\begin{array}{l}\text { Reluctant on } \\
\text { petting the } \\
\text { horse can lead } \\
\text { to negative } \\
\text { emotional } \\
\text { response. }\end{array}$ & & & & & & \\
\hline $\begin{array}{l}\text { The child } \\
\text { refuse to } \\
\text { wear riding } \\
\text { helmet. }\end{array}$ & $\begin{array}{l}\text { Refusal on } \\
\text { wearing riding } \\
\text { helmet may } \\
\text { disturb THR } \\
\text { session and not } \\
\text { safe for the } \\
\text { rider. }\end{array}$ & & & & & & \\
\hline $\begin{array}{l}\text { The child } \\
\text { disliking } \\
\text { socks and } \\
\text { shoes or } \\
\text { avoiding } \\
\text { walking } \\
\text { barefoot. }\end{array}$ & $\begin{array}{l}\text { Any denial to } \\
\text { do simple task } \\
\text { may lead to } \\
\text { negative } \\
\text { reaction and } \\
\text { not suitable for } \\
\text { THR session } \\
\text { yet. }\end{array}$ & & & & & & \\
\hline $\begin{array}{l}\text { The child } \\
\text { avoiding or } \\
\text { overreacting } \\
\text { to wet or } \\
\text { messy } \\
\text { textures. }\end{array}$ & $\begin{array}{l}\text { THR could be } \\
\text { harmful } \\
\text { activities and } \\
\text { not suitable for } \\
\text { the kids that } \\
\text { are unstable } \\
\text { sense of touch. }\end{array}$ & & & & & & \\
\hline $\begin{array}{l}\text { The child is } \\
\text { over } \\
\text { sensitivity to } \\
\text { temperature } \\
\text { or decreased } \\
\text { awareness of } \\
\text { extreme } \\
\text { temperatures. }\end{array}$ & $\begin{array}{l}\text { The children } \\
\text { who join THR } \\
\text { need to be } \\
\text { easily } \\
\text { adaptable to } \\
\text { the temperature } \\
\text { surrounding as } \\
\text { it affects } \\
\text { emotional } \\
\text { response. }\end{array}$ & & & & & & \\
\hline $\begin{array}{l}\text { The child } \\
\text { frequently } \\
\text { dropping } \\
\text { objects out of } \\
\text { their hands. }\end{array}$ & $\begin{array}{l}\text { This behavior } \\
\text { might lead to } \\
\text { frustration and } \\
\text { not giving } \\
\text { commitment } \\
\text { during the } \\
\text { THR session. }\end{array}$ & & & & & & \\
\hline $\begin{array}{l}\text { The child } \\
\text { showing } \\
\text { irritation over } \\
\text { particular } \\
\text { types of } \\
\text { clothing such } \\
\text { as jerseys or } \\
\text { jeans. }\end{array}$ & $\begin{array}{l}\text { Appropriate } \\
\text { attire is } \\
\text { necessary to } \\
\text { participate in } \\
\text { THR activity. }\end{array}$ & & & & & & \\
\hline
\end{tabular}

\subsection{Vestibular (Balance)}

The vestibular system is including in the most basic sense. This system helps maintain balance, coordination, posture and muscle tone. Vestibular processing problems can present as hypo or hyper responsive and threaten many aspects of everyday life. The vestibular system is very important in helping to regulate body. This important sensory system underpins many other body and mind functions [19]. The following is Table 4 that comprise of the vestibular related items in order to evaluate the ASD children before involve in THR session.

\section{Table 4 Vestibular}

\begin{tabular}{|c|c|c|c|c|c|c|c|}
\hline \multicolumn{8}{|c|}{ Vestibular } \\
\hline \multirow{2}{*}{ Items } & \multirow{2}{*}{ Justification } & \multicolumn{4}{|c|}{ Scores } & \multicolumn{2}{|c|}{ Marks } \\
\hline & & 1 & 2 & 3 & 4 & $V$ & $\mathrm{x}$ \\
\hline $\begin{array}{l}\text { The child } \\
\text { easily to gets } \\
\text { upset while } \\
\text { performing } \\
\text { balancing } \\
\text { task on } \\
\text { balance beam } \\
\text { or board. }\end{array}$ & $\begin{array}{l}\text { The child } \\
\text { who have } \\
\text { difficulties in } \\
\text { performing } \\
\text { vestibular- } \\
\text { related task, } \\
\text { might give } \\
\text { negative } \\
\text { response } \\
\text { when they } \\
\text { are on horse. }\end{array}$ & & & & & & \\
\hline $\begin{array}{l}\text { The child } \\
\text { scared of } \\
\text { heights; } \\
\text { hesitates } \\
\text { going up or } \\
\text { down while } \\
\text { carrying out } \\
\text { climbing } \\
\text { task. }\end{array}$ & $\begin{array}{l}\text { The child } \\
\text { could scream } \\
\text { on horse. As } \\
\text { screaming or } \\
\text { loud noises } \\
\text { may disturb } \\
\text { the horse. } \\
\text { This might } \\
\text { bias the } \\
\text { safety during } \\
\text { the THR } \\
\text { session } \\
\text { conducted. }\end{array}$ & & & & & & \\
\hline $\begin{array}{l}\text { The child } \\
\text { loses balance } \\
\text { unexpectedly } \\
\text { when } \\
\text { walking on } \\
\text { uneven } \\
\text { space. }\end{array}$ & $\begin{array}{l}\text { The child has } \\
\text { tendency to } \\
\text { give poor } \\
\text { response or } \\
\text { crying on } \\
\text { horse as they } \\
\text { frightened } \\
\text { with height }\end{array}$ & & & & & & \\
\hline $\begin{array}{l}\text { The child has } \\
\text { less } \\
\text { determinatio } \\
\mathrm{n} \text { while } \\
\text { riding a } \\
\text { bicycle. }\end{array}$ & $\begin{array}{l}\text { when they } \\
\text { loss their } \\
\text { balance. }\end{array}$ & & & & & & \\
\hline
\end{tabular}




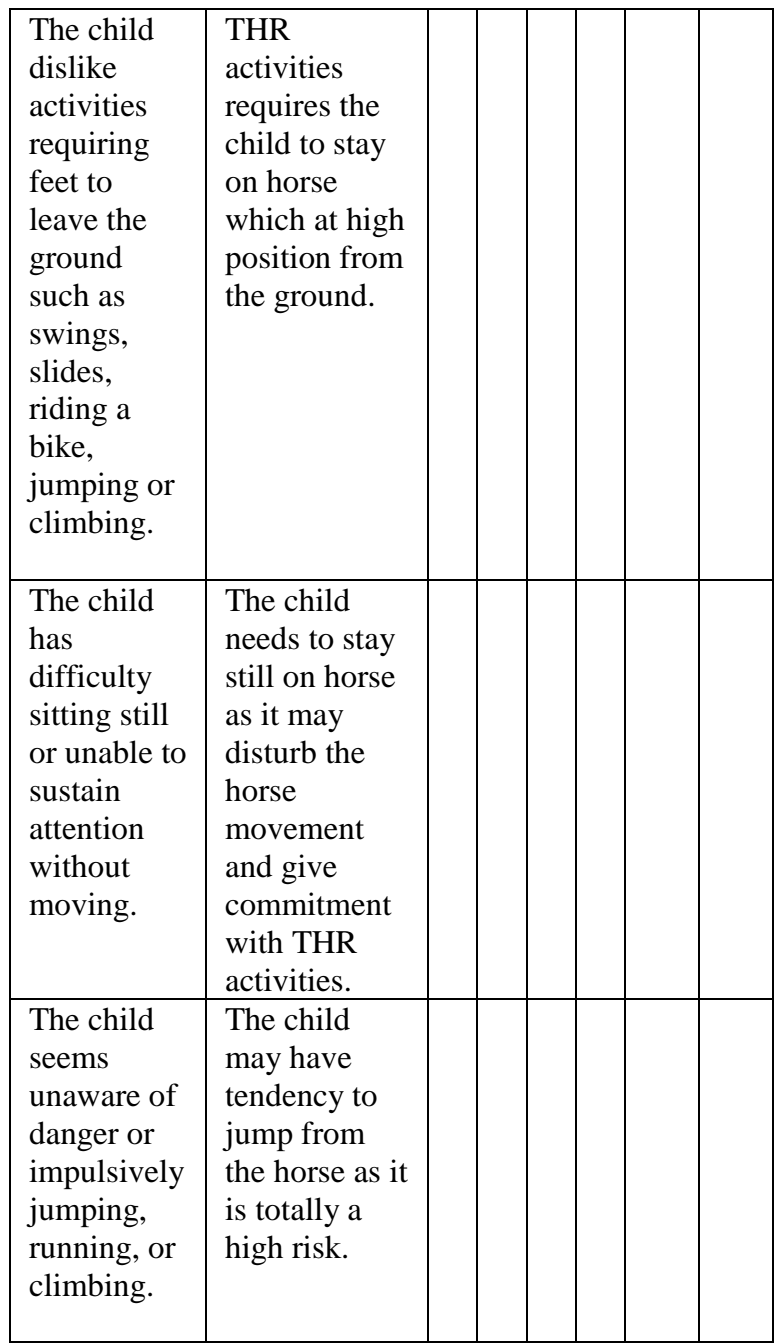

\subsection{Proprioception (Body Awareness)}

Proprioceptive input helps body to know where the different parts of body are, how they are moving, and how much strength our muscles need to use. This system provides information that is used for motor movements and postural control [19]. It is also sense if something unexpected happens. Proprioception, sometimes referred to as the sixth sense and knows what position it is in. This system helps to sense which limbs are in space and how hard the body are pressing, pushing or pulling. The individual may struggle to behave according to the environmental requirements when sensory processing is dysfunction, thus contributing to wider functional difficulties [20]. Table 5 justify the items included in proprioception section that need to be assess on ASD children before enrols in THR activities.
Table 5 Proprioception

\begin{tabular}{|c|c|c|c|c|c|c|c|}
\hline \multicolumn{8}{|c|}{ Proprioception } \\
\hline \multirow{2}{*}{ Items } & \multirow{2}{*}{ Justification } & \multicolumn{4}{|c|}{ Scores } & \multicolumn{2}{|c|}{ Marks } \\
\hline & & 1 & 2 & 3 & 4 & $V$ & $x$ \\
\hline $\begin{array}{l}\text { The child } \\
\text { frequently } \\
\text { make } \\
\text { attempt for } \\
\text { climbing, } \\
\text { falling, } \\
\text { crashing or } \\
\text { jumping. }\end{array}$ & $\begin{array}{l}\text { Any sudden } \\
\text { attempt and } \\
\text { movement of } \\
\text { the child } \\
\text { may trigger } \\
\text { spooky } \\
\text { horse. }\end{array}$ & & & & & & \\
\hline $\begin{array}{l}\text { The child } \\
\text { frequent } \\
\text { kicking } \\
\text { while } \\
\text { sitting or } \\
\text { stomping } \\
\text { feet while } \\
\text { walking. }\end{array}$ & $\begin{array}{l}\text { The active } \\
\text { feet of the } \\
\text { child may } \\
\text { aid the cues } \\
\text { to the horse } \\
\text { to increase } \\
\text { the gait } \\
\text { movement. }\end{array}$ & & & & & & \\
\hline $\begin{array}{l}\text { The child } \\
\text { often plays } \\
\text { too rough } \\
\text { with peers, } \\
\text { siblings or } \\
\text { pets. }\end{array}$ & $\begin{array}{l}\text { There is risk } \\
\text { during THR } \\
\text { session as } \\
\text { they may } \\
\text { misbehaved } \\
\text { while on } \\
\text { horse. }\end{array}$ & & & & & & \\
\hline $\begin{array}{l}\text { The child } \\
\text { often } \\
\text { bumping or } \\
\text { crashing } \\
\text { into things } \\
\text { or other } \\
\text { people. }\end{array}$ & $\begin{array}{l}\text { The } \\
\text { unexpected } \\
\text { action from } \\
\text { the child } \\
\text { may disturb } \\
\text { the THR } \\
\text { activities. }\end{array}$ & & & & & & \\
\hline $\begin{array}{l}\text { The child } \\
\text { using too } \\
\text { much force } \\
\text { in carrying } \\
\text { or opening, } \\
\text { resulting in } \\
\text { dropping, } \\
\text { spillage or } \\
\text { breakage. }\end{array}$ & $\begin{array}{l}\text { This child } \\
\text { may lead to } \\
\text { negative } \\
\text { emotional } \\
\text { response } \\
\text { during the } \\
\text { THR } \\
\text { session. }\end{array}$ & & & & & & \\
\hline $\begin{array}{l}\text { The child } \\
\text { has } \\
\text { difficulty } \\
\text { climbing } \\
\text { stairs, } \\
\text { riding a } \\
\text { bicycle or } \\
\text { standing on } \\
\text { one foot. }\end{array}$ & $\begin{array}{l}\text { The } \\
\text { struggling } \\
\text { with those } \\
\text { activities } \\
\text { shows lack } \\
\text { in body } \\
\text { coordination } \\
\text { which may } \\
\text { lead to } \\
\text { safety bias. }\end{array}$ & & & & & & \\
\hline
\end{tabular}




\subsection{Auditory (Sense of hearing)}

The auditory system refers to our ability to receive, process and respond appropriately [21]. Auditory defensiveness or hyperacusis may result in discomfort or painful response to noise, often especially certain types of noise [22]. Noise level is high for some persons with hyperacusis and are able to hear sounds that others cannot hear [23]. Auditory system also essential to assess on ASD children as it is including in safety measures. Table 6 consist of each item that involve to determine the auditory sensory processing in children with ASD as prerequisite before attend THR session.

Table 6 Auditory

\begin{tabular}{|c|c|c|c|c|c|c|c|}
\hline \multicolumn{8}{|c|}{ Auditory } \\
\hline \multirow{2}{*}{ Items } & \multirow{2}{*}{ Justification } & \multicolumn{4}{|c|}{ Scores } & \multicolumn{2}{|c|}{ Marks } \\
\hline & & 1 & 2 & 3 & 4 & $\checkmark$ & $x$ \\
\hline $\begin{array}{l}\text { The child } \\
\text { enjoys } \\
\text { making noise } \\
\text { just to make } \\
\text { noise. }\end{array}$ & $\begin{array}{l}\text { Sudden loud } \\
\text { noise or scream } \\
\text { from the child } \\
\text { may anxious } \\
\text { the horse as } \\
\text { their natural } \\
\text { instinct fight } \\
\text { and flight } \\
\text { response. }\end{array}$ & & & & & & \\
\hline $\begin{array}{l}\text { The child } \\
\text { overreacts to } \\
\text { loud or } \\
\text { unexpected } \\
\text { sounds } \\
\text { (covering } \\
\text { ears, crying, } \\
\text { running } \\
\text { away). }\end{array}$ & $\begin{array}{l}\text { THR session } \\
\text { could be } \\
\text { harmful and not } \\
\text { suitable for the } \\
\text { kids yet as this } \\
\text { criterion may } \\
\text { enhance } \\
\text { negative } \\
\text { emotional } \\
\text { response. }\end{array}$ & & & & & & \\
\hline $\begin{array}{l}\text { The child } \\
\text { annoyed or } \\
\text { distracted by } \\
\text { sounds that } \\
\text { most of us do } \\
\text { not notice. }\end{array}$ & $\begin{array}{l}\text { They can be } \\
\text { very sensitive } \\
\text { and disturbed } \\
\text { while on horse } \\
\text { and unable to } \\
\text { commit with } \\
\text { activities. }\end{array}$ & & & & & & \\
\hline $\begin{array}{l}\text { The child } \\
\text { often } \\
\text { becomes } \\
\text { upset with } \\
\text { others for } \\
\text { being too } \\
\text { loud. }\end{array}$ & $\begin{array}{l}\text { Easily upset } \\
\text { with simple } \\
\text { task may lead } \\
\text { to negative } \\
\text { emotional } \\
\text { response and } \\
\text { not suitable for } \\
\text { THR session. }\end{array}$ & & & & & & \\
\hline
\end{tabular}

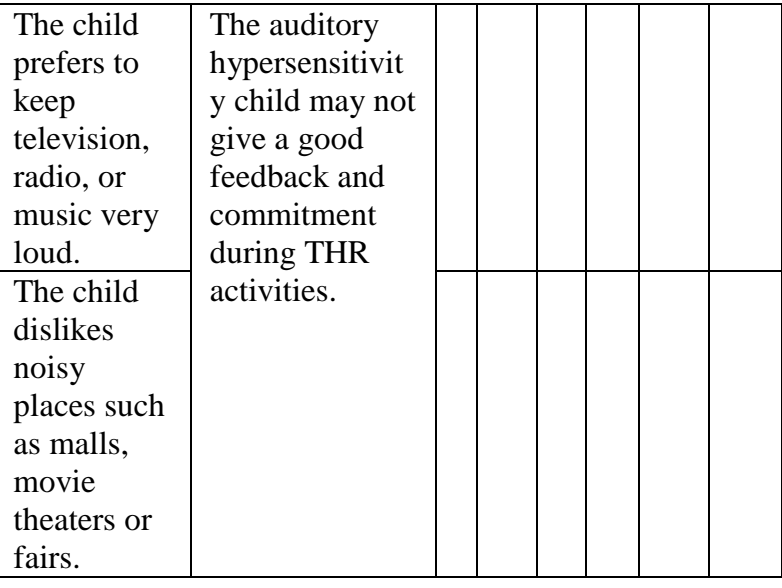

\section{DISCUSSION}

The degree of sensory difficulties in different domains can affect functioning in many different activities of daily living. Research in sensory processing suggests that children with autism process sensory information differently than typical children [23]. With the growing positive evidence of therapeutic horseback riding on autism spectrum disorder, this research makes a deliberate attempt to come out with this standard guideline for this alternative therapy. Identifying sensory issue on tactile system in children with ASD is essential before participating in THR session. There are seven (7) items in the tactile elements. Each item with score of two (2) and above can proceed with THR. In the tactile section, the children must obtain score of two (2) and above for at least in five (5) over seven (7) items to at least proceed with THR. Tactile systems are important to consider before participating THR session as any refusal on performing task like wearing helmet and shoes may disturb THR session and not safe for the rider. THR could be a risk activity and not suitable for the kids that are unstable with sense of touch.

Vestibular is also a part of fundamental sense that should be evaluate before the children involve in THR session. The child who have difficulties in performing vestibularrelated task, might act differently or give negative response when they are on horse. They may scare of heights or easily loses balance that make them not ready yet to proceed in THR session. There are seven (7) items in the vestibular sections. Each item with score of two (2) and above for at least in five (5) over seven (7) items has to be obtain by the ASD children to at least proceed with THR. Vestibular system is important to consider as it is closely related with balance and coordination [20]. The child with difficulties in vestibular processing need further consultation with their therapist before participate in THR activity.

Proprioceptive processing difficulties of ASD children may arise risk during THR session as they may misbehaved while on horse. It is in need to assess their 
proprioception before enrols in THR session. The child with proprioception difficulties have tendency to make attempt for climbing, falling, crashing or jumping [20]. Any sudden attempt and movement of the child may trigger spooky horse. There are six (6) items listed in the proprioception section. The ASD children need to pass four (4) over six (6) items with score two (2) and above to make them qualify to proceed with THR.

Moreover, auditory system also is including in order to evaluate the child sensory processing. The ASD child with difficulties in auditory processing have tendency to make a sudden loud noise and scream or overreacts to loud or unexpected sounds. This may anxious the horse as their natural instinct is fight and flight response. It is vital to avoid the horse to spooky during the THR session as it is very dangerous for the rider. In auditory section, there are six (6) items comprises. Each item with score of two (2) and above for at least in three (3) over six (6) items to at least proceed with THR. However, children with auditory and visual disabilities able to proceed with THR sessions with a professional guidance from the person in charge.

\section{LIMITATIONS}

The limitation of this study is specific to sensory elements in the learning pyramid which only focusing on tactile, vestibular, proprioception and auditory. The proposed guideline can be applicable to therapeutic horseback riding community. In addition, one limitation of the proposed guideline is that we have had limited collaboration opportunities with other regulatory body or establishment that conduct therapeutic horseback riding on autism spectrum disorder. However, engagement with Riding for the Disabled Association (RDA) is included.

\section{ACKNOWLEDGMENT}

The data presented, the statements made, and the views expressed are solely the responsibility of the author. We thank the anonymous referees for their useful thoughts and knowledge contribution.

\section{IMPLICATIONS}

The proposed THR standard guidelines based on an integrative health care approach have several implications. First, this guideline can serve as a foundational resource to guide therapeutic horseback riding community. Moreover, the discoveries of this study would suggest the guideline as a safety measures that need to be considered before ASD children participating in THR sessions. In addition, this study will come up to the improvement of horse-riding therapy in Riding for Disabled Association (RDA) Malaysia. The outcome from this research could contribute to the body of knowledge in this field. Moreover, this study helps in providing awareness to community in Malaysia regarding THR activities and its benefits. Therefore, horse riding therapy would be preferred alternative therapy for children with ASD.

\section{CONCLUSIONS}

THR standard guidelines signify an essential outset as a primary maneuverer to support and direct therapeutic horseback riding community. Furthermore, these guidelines can be developed with further refinement as this study acknowledge that the proposed guideline is comprehensive. Above all, the person in charge for the THR session which involve children with ASD is accountability for the safety of all participants, include rider, horses, helpers and spectators. There are different beliefs, philosophies, and school of thought in this particular fields. Nonetheless, the objective or goals of the therapy is paramount. This study proposes a guideline to obtain a score of the sensory elements for ASD kids to qualify for THR without prejudice the safety aspects. The standard guideline initiate from this study shall be adequate enough for ASD children and can be use as prerequisite before they participating any horse-riding therapy session.

\section{REFERENCES}

[1] Srinivasan, S. M., Cavagnino, D. T., \& Bhat, A. N. (2018). Effects of Equine Therapy on Individuals with Autism Spectrum Disorder: A Systematic Review.

Review Journal of Autism and Developmental

Disorders, 5(2), 156-175. DOI:

https://doi.org/10.1007/s40489-018-0130-z

[2] American Psychiatric Association. (2013).

Diagnostic and statistical manual of mental disorders (5th ed.). Arlington, VA: American Psychiatric Association.

[3] Ozonoff, S., Pennington, B.F., \& Rogers, S.J. (2006). Executive function deficits in high-functioning autistic individuals: relationship to theory of mind. Journal of Child Psychology and Psychiatry, 32(7), 
1081-1105. DOI: https://doi.org/10.1111/j.14697610.1991.tb00351.x.

[4] Fournier, K. A., Hass, C. J., Naik, S. K., Lodha, N., \& Cauraugh, J. H. (2010). Motor coordination in autism spectrum disorders: a synthe- sis and meta-analysis. Journal of Autism and Developmental Disorders, 40, 1227-1240. DOI: https://doi.org/10.1007/s10803-0100981-3.

[5] Feather, K. A. (2015). Low Functioning to High Functioning Autism: A Prescriptive Model for Counselors Working with Children Across the Spectrum. (2013), 1-15.

[6] Boucher, J., Mayes, A., \& Bigham, S. (2012). Memory in autistic spectrum disorder. Psychological bulletin, 138(3), 458 .

[7] Hall, H. R., \& Graff, J. C. (2011). The relationships among adaptive behaviors of children with autism, family support, parenting stress, and coping. Issues in comprehensive pediatric nursing, 34(1), 4-25.

[8] Lopata, C., Thomeer, M. L., Volker, M. A., Toomey, J. A., Nida, R. E., Lee, G. K., ... \& Rodgers, J. D. (2010). RCT of a manualized social treatment for high-functioning autism spectrum disorders. Journal of autism and developmental disorders, 40(11), 12971310.

[9] Deficits, E., Social, I. N., Interaction, S., Contexts, A., For, A., General, B. Y., ... By, M. (2013). Dsm - 5 a. (February).

[10] Perron, J. A. (2016). What factors influence horse behavior in the equine assisted activities and therapy environment? (Doctoral dissertation, University of New Hampshire).

[11] Harrington, J. W., Rosen, L., Garnecho, A. N. A., \& Patrick, P. A. (2006). Parental perceptions and use of complementary and alternative medicine practices for children with autistic spectrum disorders in private practice. Journal of Developmental \& Behavioral Pediatrics, 27(2), S156-S161.

[12] Lee, L. C., Harrington, R. A., Chang, J. J., \& Connors, S. L. (2008). Increased risk of injury in children with developmental disabilities. Research in developmental disabilities, 29(3), 247-255.

[13] Mazefsky, C. A., Pelphrey, K. A., \& Dahl, R. E. (2012). The need for a broader approach to emotion regulation research in autism. Child development perspectives, 6(1), 92-97.
[14] British Horse Society. British Horse Society (2003). Some Equestrian Statistics [online]. Available from: http://www.bhs.org.uk/AccessLeaflets/ Access24.htm [Date accessed 21.7.03].

[15] Williams, M. S., \& Shellenberger, S. (1994). The alert program for self-regulation. Sensory Integration Special Interest Section Newsletter, 17(3), 1-3.

[16] Rutter, M., Bailey, A., \& Lord, C. (2003). The social communication questionnaire: Manual. Western Psychological Services.

[17] Mikkelsen, M., Wodka, E. L., Mostofsky, S. H., \& Puts, N. A. (2018). Autism spectrum disorder in the scope of tactile processing. Developmental cognitive neuroscience, 29, 140-150.

[18] O’Connor, C., Lambe, S., Gleeson, S., \& Henry, Á. (2016) Facilitating children's sensorimotor* development in DEIS schools.

[19] Blanche, E. I., Reinoso, G., Chang, M. C., \& Bodison, S. (2012). Proprioceptive processing difficulties among children with autism spectrum disorders and developmental disabilities. American Journal of Occupational Therapy, 66(5), 621-624.

[20] Suarez, M. A. (2012). Sensory processing in children with autism spectrum disorders and impact on functioning. Pediatric Clinics, 59(1), 203-214.

[21] Posar, A., \& Visconti, P. (2018). Sensory abnormalities in children with autism spectrum disorder. Jornal de Pediatria (Versão em Português), 94(4), 342-350.

[22] Kern, J.K., Miller, V. S., Cauller, L.J., Kendall, R., Mehta, J. \& Dodd, M. (2001) 'The Effectiveness of N, N-Dimethylglycine in Autism/PDD', Journal of Child Neurology 16 (3): 169-73.

[23] Kern, J. K., Trivedi, M. H., Garver, C. R., Grannemann, B. D., Andrews, A. A., Savla, J. S., ... \& Schroeder, J. L. (2006). The pattern of sensory processing abnormalities in autism. Autism, 10(5), 480494. 